\title{
Poems about Alzheimer disease
}

\author{
Cite as: CMAJ 2018 June 25;190:E770. doi: 10.1503/cmaj.180424
}

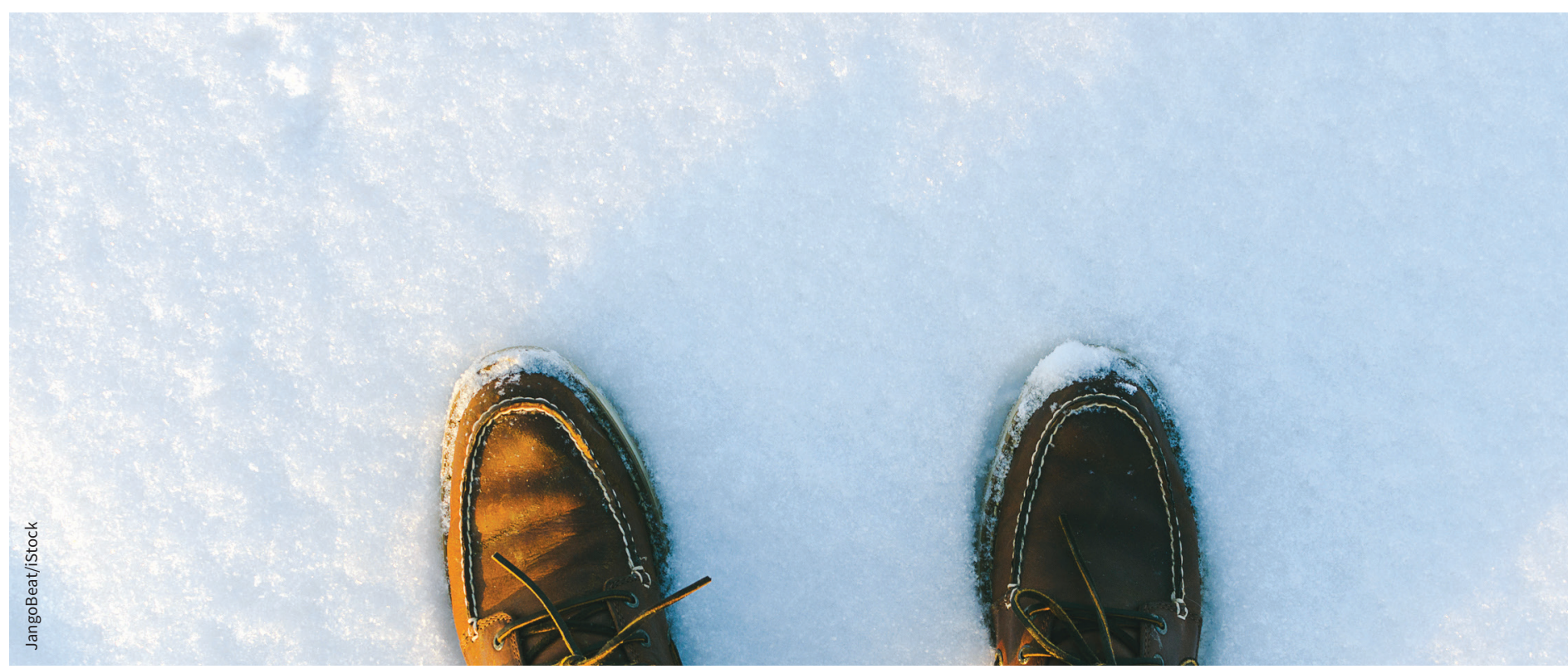

\section{January storm}

When I say he wandered out into the snow in his slippers there is no account to which he can tally it.

He remembers nothing of panic or fear, houses in the dark, ringing a doorbell to tell a neighbour he is lost.

Much like he can't account for the tally of bruises each time he loses his balance, each time he is scored again, it's like ringing a doorbell and finding no one home, lost collisions that we pattern into what we call a day, a week.

What do we call the lost balance of time, scoreless? What gain to argue facts with him, or repeat endlessly what he has missed? We collide with his pattern that is no pattern, year, day, week. In that stranger's kitchen he knew his phone number, no address.

He had facts enough to repeat a code to safety. Not all amiss, still an instinct for survival in the blackout, while some days his own kitchen is a stranger's, no phone, no address, no need to say he walked out in the snow to slip away.

\section{Name}

I say "Father" in every sentence.

It is reassurance, a qualifier for every statement and action of what is a new method of love.

Is he reassured? Am I? Each line I qualify, I ask this magic word to prove itself, to be what and why in a game, rote-love proof here is staying in the room

to ask questions, magic to prove himself still there. Father, irascible, bruised, bled. All proofs here are staid. We are this room named father/son, a skein of connection

stilled there, a shade, irascible, bruised, bled. The call and response clumsier each visit, playing at son, paper skinned connection. I say "Father" sometimes like a sentence.

\section{Robert Colman MFA}

Newmarket, Ont.

This article has not been peer reviewed. 